\author{
Adama SAMAKE ${ }^{1}$ \\ Piotr KOCANDA ${ }^{2}$ \\ Andrzej KOS ${ }^{3}$
}

\title{
IMPROVEMENT OF MICROSYSTEM THROUGHPUT USING NEW COOLING SYSTEM
}

\begin{abstract}
This paper presents a new possibility of clock frequency/voltage control in microsystems i.e. high performance processors, exploiting information about cooling efficiency. In this paper, we propose an approach that better exploits the thermal abilities of a chip fixed to cooling system in order to eliminate its energy accumulation. For the purpose of the proposed method, the calculation of so called time shift (TS) is introduced. TS is defined as the duration where the computational system can perform the task at higher frequency without any thermal violation when the chip temperature is close to critical thermal threshold. The analogy between thermal and electrical parameters allows to model RC thermal compact model of structure (chip fixed to the cooling system). Based on this assumption, the authors compute the TS value versus different parameters using RC thermal compact model in Spice environment. The results indicate that TS could fulfil a significant part of die total working time. As an effect the proposed approach may be a means for increasing average clock frequency or voltage supply, consequently enhancing the system's throughput.
\end{abstract}

Keywords: clock frequency, voltage supply, heat pipes, temperature sensors, throughput of microprocessor

\section{Introduction}

Since, the high power computation systems demand has been growing up enormously in the market, the amount of electronic components per unit area in the integrated circuit interior has been raising exponentially. As a result, the power density generated by the components has become significantly important

\footnotetext{
${ }^{1}$ Adama Samake, AGH University of Science and Technology, Faculty of Computer Science, Electronics and Telecommunications, Al. Mickiewicza 30, Krakow, Poland, PhD Student from Mali

${ }^{2}$ Piotr Kocanda, AGH University of Science and Technology, Faculty of Computer Science, Electronics and Telecommunications, Al.Mickiewicza 30, Krakow, Poland, PhD Student

${ }^{3}$ Corresponding author: Andrzej Kos, AGH University of Science and Technology, Faculty of Computer Science, Electronics and Telecommunications, Al. Mickiewicza 30, Krakow, Poland, e-mail: kos@agh.edu.pl
} 
thus allowing the chip to overheat. Consequently, it causes enormous issues such as the increasing of cooling cost, performance decreasing and poor reliability of the chip [9].

Recently statistics results have shown that the major causes of chip failures are due to the inappropriate thermal design of electronic systems [12]. Taking into account all these aspects provoked by chip overheating, monitoring and controlling of the electronic systems temperature is crucial in order to achieve the highest possible data processing efficiency and reliability [4].

Removing the heat using fan from a heat sink attached to a package (integrated circuit) and Dynamic Frequency Voltage Scaling (DFVS) are considered as a conventional thermal management $[1,3]$. The temperature of an element (chip, heat sink, etc.) in the electronic system depends on its own temperature and the temperature of the neighboring elements. Taking into account this fact, the current data collected from heat sink edge (temperature sensor) about cooling efficiency may be exploited as a way to control the clock generator frequency of the integrated circuit by taking advantage of its characteristics. It targets on allowing more time for chip to operate in highest frequency and enhances its performance. Conventionally, as the temperature of chip reaches a predefined thermal threshold, the DFVS technique tends to decrease the operating frequency and voltage by degrees. As a matter of fact it increases the lifetime of given process. Hence, it is important to underline that the method proposed in this paper can be implemented without any modification of system micro-architecture, the only requirement is the attachment of one temperature sensor in appropriate place on the heat sink.

Monitoring and controlling chip temperature using phase change techniques presents a huge advantage in terms of power (heat) transfer [5]. During transition temperature it is capable to remove latent heat under isothermal condition. According to numerous investigations, many substances possess higher latent heat of vaporization than latent heat of fusion [8]. Due to that reason, attaching a chip to the heat sink via heat pipe allows absorption of heat generated in the chip and releases it to the surrounding cooling air at any single moment of time. A heat pipe is a simple pipe having internal wall fixed with capillary wicking material, normally a portion of it is filled with a fluid (which could be water) [5]. The temperature of the liquid located at the end of heat pipe attached to the heat source rises continuously up to the boiling point. Whenever the liquid temperature reaches this point, it continues to absorb power (heat) while maintaining the temperature constant thus, the liquid starts to evaporate. Owing to the pressure gradient generated by the temperature difference between different parts of pipe, the vapour spreads to other region, in order to be cooled and condensed. The condensed liquid is then passively pumps back to the region attached to heat source (chip) via wick structure. Hence, the cycle continues as long as the temperature difference exists. 
This paper focuses in the introduction of a newly technique based on the possibility of clock frequency/ supply voltage control in microsystems, exploiting information about cooling efficiency. Several investigations have been done in this research area. In paper [2], the phenomenon of thermal inertia into integrated circuits has been described. In [10], a solution for online overheating protection of electronic systems has been proposed, using thermal sensor and thermal monitoring master (TMM) circuit. The use of an additional built-in circuitry to proposed technique allows offline static and transient thermal testing. In paper [13] the spray cooling of electronic chips has been investigated without using any heat sink. In [7] numerical modelling and experimental investigation have been performed to show the possibility of building a heat pipe embedded in metal core printed circuit board. The proposed technique significantly enhances heat spreading capability compared to conventional printed board. Reduction of 35$45 \%$ in thermal resistance of metal core printed circuit board has been found as the result of experimental investigation, which agrees with numeral modelling.

\section{Thermal Model}

Fig. 1 depicts the complex thermal system having thermal pipes. The integrated circuit is situated in an adiabatic surrounding and connected to the parallel plate fin heat sink with U-shape channels via heat pipe. One temperature sensor is fixed to the fin of heat sink hence, the whole system is attached to an active fan. During die activation it generates and dissipates a certain amount of power (heat). Therefore, the heat transfer from chip interior to surrounding air starts when the heat reaches the end of the heat pipe attached to the die. The thermal control of the system is focused on convection coefficient rising (turning on the fan) at heat sink level when the chip's temperature moves toward thermal threshold. This act rapidly cooled the heat sink while maintaining the constant temperature close to critical thermal threshold on the chip surface for a significant period of time. For simplification of complex thermal system, a RCcompact model has been created. The different parts of system are modelled by a high order system.

\section{Simulation of time shift versus different parameters}

As shown in the formula below, parameters are function of the geometries and physical proprieties. The duality between thermal, electrical resistances and capacitances are described in [11]. Also exists an analogy between heat source and electrical current. Notice that, the heat power can be presented either as a heat source or as a heat exchanger having proper direction (negative or positive) in a circuit [6]. Let's calculate the particular parameters: 
a)

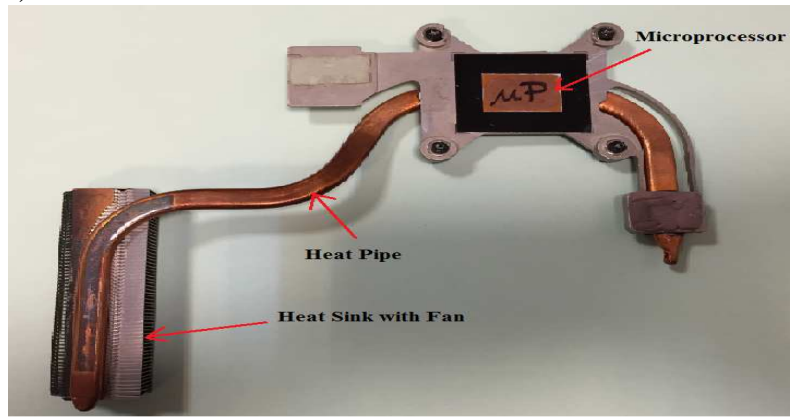

b)

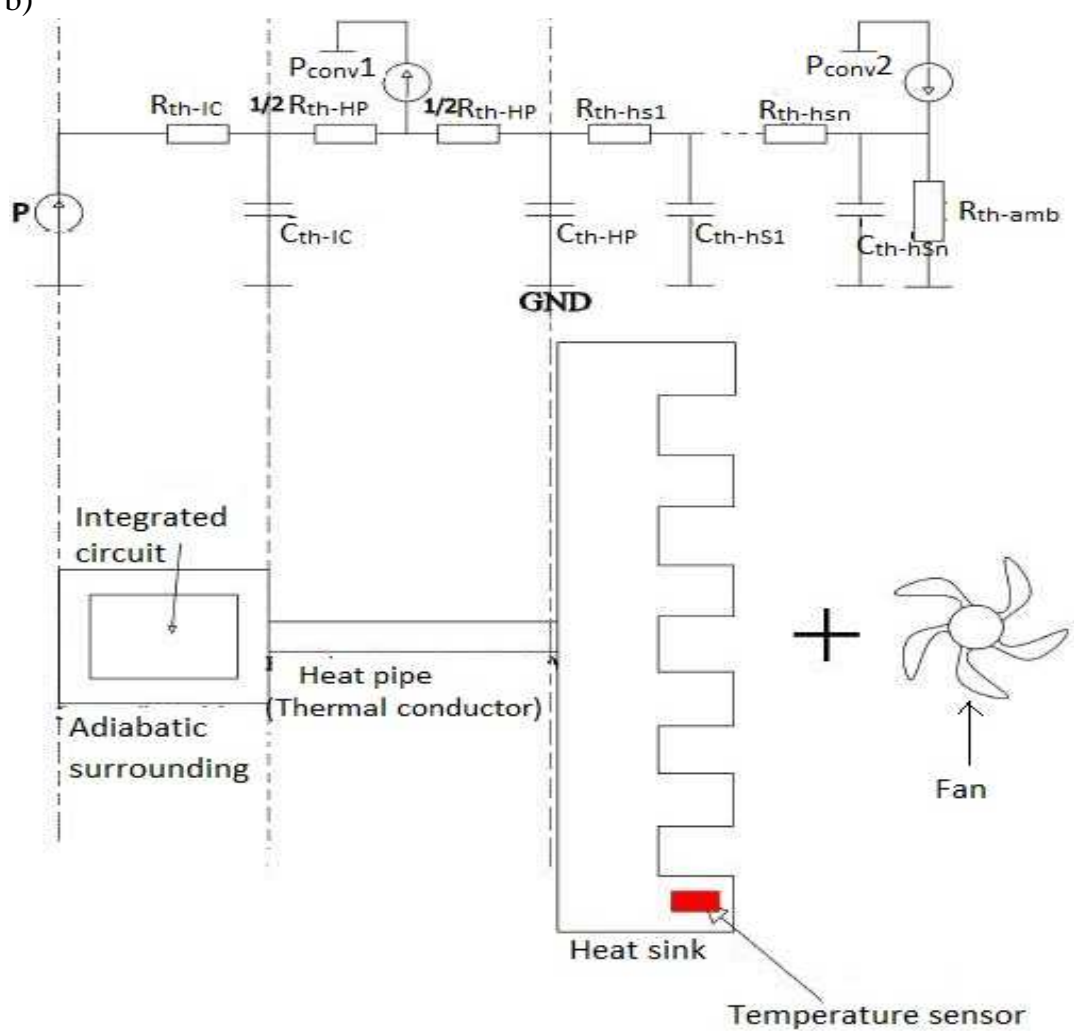

Fig.1 (a) A finned passive heat sink connected to a laptop microprocessor via a heat pipe and (b) Model of cooling system (Integrated circuits connected to parallel plate fin heat sink with U-shape channels via a heat pipe and its equivalent $\mathrm{RC}$ thermal network). Where: $\mathrm{P}$ is the power generated by the integrated circuit, $\mathrm{P}_{\text {conv }} 1$ is the power (heat) absorbed by the fluid inside heat pipe (notice that the heat pipe release power to the heat sink), $\mathrm{P}_{\text {conv } 2}$ is the power (heat) release to the ambient, $\mathrm{R}_{\text {th-IC }}$ and $\mathrm{C}_{\mathrm{th}-\mathrm{IC}}$ are the thermal resistance and capacitance of integrated circuit respectively. $\mathrm{R}_{\mathrm{th}-\mathrm{HP}}$ and $\mathrm{C}_{\mathrm{th}-\mathrm{HP}}$ are the thermal resistance and capacitance of heat pipe respectively. $\mathrm{R}_{\mathrm{th}} \mathrm{hsn}$ and $\mathrm{C}_{\mathrm{th} \text { hSn }}$ are the thermal resistance and capacitance of specific fin including surface from heat source. $\mathrm{R}_{\mathrm{th}} \mathrm{amb}$ is the thermal resistance between the heat sink and the ambient. 


$$
\mathrm{R}_{\mathrm{th}}=\frac{l}{\lambda \mathrm{S}}
$$

where: $\mathrm{R}_{\mathrm{th}}$ is the thermal resistance in $\mathrm{KW}^{-1}$

$l$ is the distance between two points in $\mathrm{m}$

$\mathrm{S}$ is the area in $\mathrm{m}^{2}$

$\lambda$ is the thermal conductivity in $\mathrm{Wm}^{-1} \mathrm{~K}^{-1}$

$$
\mathrm{C}_{\mathrm{th}}=\mathrm{Mc}_{\mathrm{p}}=\mathrm{e} \rho \mathrm{Sc}_{\mathrm{p}}
$$

where: $\mathrm{C}_{\text {th }}$ is the thermal capacitance in $\mathrm{J} \mathrm{K}^{-1}$

$\mathrm{M}$ is the mass in $\mathrm{kg}$

$c_{p}$ is the specific heat in $\mathrm{Jkg}^{-1} \mathrm{~K}^{-1}$

$\rho$ is the density in $\mathrm{kg} \mathrm{m}^{-3}$

$\mathrm{e}$ is the thickness of material in $\mathrm{m}$

Hence, the resistance between the heat sink and ambient may be obtained by using the formula bellow [2].

$$
\mathrm{R}_{\mathrm{amb}}=\frac{1}{\mathrm{hS}}
$$

where: $R_{a m b}$ is ambient thermal resistance in $\mathrm{KW}^{-1}$

$\mathrm{h}$ is the general convection coefficient in $\mathrm{Wm}^{-2} \mathrm{~K}^{-1}$

The unsteady state thermal effect of each element in electronic system depends on its own temperature and the temperature of neighboring elements. Therefore, the Spice model focus on duality between thermal and electrical parameters could be used to prove the advantage of our idea to use additional temperature sensor on the edge of heat sink. In the beginning let's define a time shift, the time shift (TS) value is the duration of almost constant temperature close to the critical thermal threshold on the chip surface while accelerating the frequency generator or increasing voltage supply at the same time (when the cooling efficiency is increasing), Fig.2. Our purpose is to investigate how to increase chip computation efficiency by exploiting current data (from temperature sensor) about cooling system. The simulation performed by Spice provided the TS value versus different parameters such as power absorbed by the heat pipe and pipe diameter. The simulation was performed under variable convection coefficient, with constant power generated by the chip. For its purposes, the heat absorbed/released (latent heat removed) by the fluid in heat pipe was between 10 and $40 \%$ of total power generated by the die. Thus the chip is modelled by one resistance, one capacitance and one positive current source. The heat pipe by two resistances, one capacitance and one negative current source whereas every heat fins of heat sink by one resistance and one capacitance. Table1 contains parameters of thermal system. 


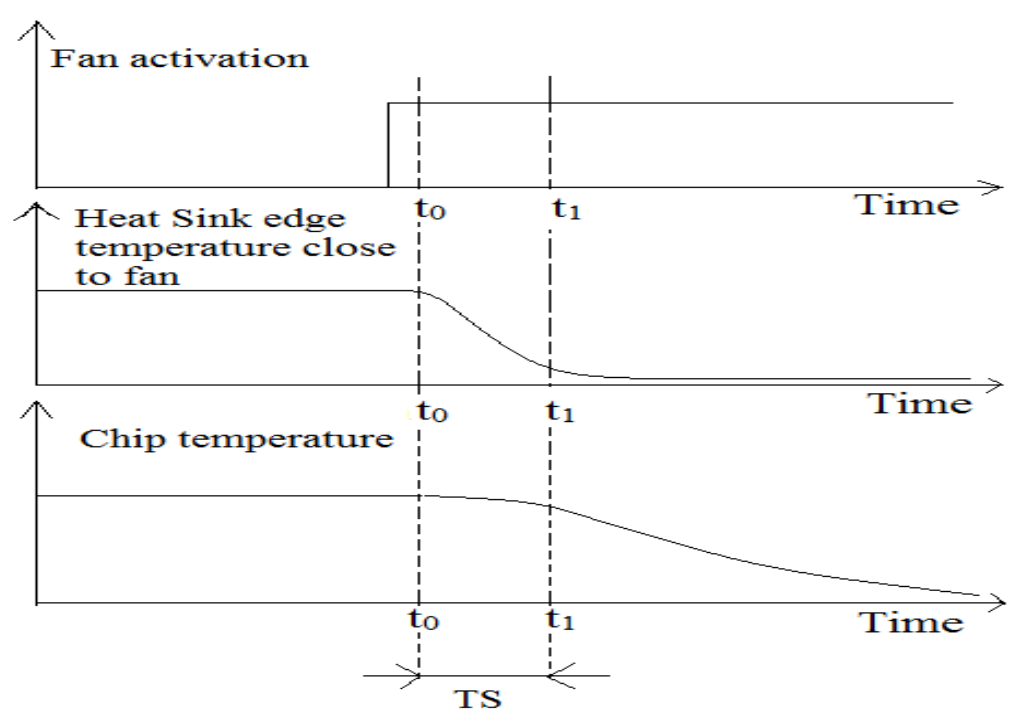

Fig.2 Temperature in different parts of the cooling system. (Quick reaction of heat sink and slow of chip).

Table.1 Parameters of thermal system under investigation.

\begin{tabular}{|c|c|c|}
\hline Parameter Name & Symbol & Values \\
\hline Heat sink fin thickness & $\varepsilon$ & $10^{-3} \mathrm{~m}$ \\
\hline Heat sink fin height & $b$ & $910^{-2} \mathrm{~m}$ \\
\hline Distance between heat sink fins & $\mathrm{Z}$ & $410^{-2} \mathrm{~m}$ \\
\hline Heat sink base width & $\mathrm{g}$ & $610^{-2} \mathrm{~m}$ \\
\hline Heat sink base length & $\mathrm{L}$ & $1810^{-2} \mathrm{~m}$ \\
\hline Base thickness & $\beta$ & $210^{-2} \mathrm{~m}$ \\
\hline thermal conductivity of heat sink & $\lambda$ & $205 \mathrm{Wm}^{-1} \mathrm{~K}^{-1}$ \\
\hline Heat pipe parameters & $\begin{array}{l}\lambda^{\prime} ; c_{\mathrm{p}}^{\prime} ; \rho^{\prime} ; \text { its diame- } \\
\text { ter length and thick- } \\
\text { ness are respectively }\end{array}$ & $\begin{array}{l}25000 \mathrm{Wm}^{-1} \mathrm{~K}^{-1} ; 390 \mathrm{Jkg}^{-} \\
{ }^{1} \mathrm{~K}^{-1} ; 8901 \mathrm{kgm}^{-3} ; 4 ; 6 ; 8 ; \\
1010^{-3} \mathrm{~m} ; 1510^{-2} \mathrm{~m} \text { and } 5 \\
10^{-4} \mathrm{~m}\end{array}$ \\
\hline $\begin{array}{l}\text { Convection coefficient(free and } \\
\text { forced) }\end{array}$ & $\mathrm{h}$ & 10 and $100 \mathrm{Wm}^{-2} \mathrm{~K}^{-1}$ \\
\hline $\begin{array}{l}\text { Power dissipated in chip and chip } \\
\text { dimension }\end{array}$ & $\mathrm{P}$ & $\begin{array}{l}10 \mathrm{~W} \text { and } 30 \times 30 \times 610^{-3} \\
\mathrm{~m}\end{array}$ \\
\hline Density of heat sink & $\rho$ & $2707 \mathrm{~kg} \mathrm{~m}^{-3}$ \\
\hline Specific heat of heat sink & $c_{p}$ & $894 \mathrm{Jkg}^{-1} \mathrm{~K}^{-1}$ \\
\hline
\end{tabular}

The TS will be used for describing the time required to keep the chip temperature constant near critical thermal threshold while accelerating the clock frequency. The time shift values were calculated versus different parameters: power absorbed or released by the heat pipe and pipe diameter thus the detailed algorithm of TS calculation is described in the next section. 


\section{Detailed time shift computation algorithm}

The heat generated inside a chip placed in adiabatic environment is rejected into surrounding air via heat pipe and heat sink. As shown in Fig.3 the step by step calculation method of thermal parameters was based on some analytical equations. Their values were used in RC circuit and the simulation varying convection coefficient versus time was performed by an electrical simulator (computer program) called LTspiceIV. The analogies existing between electrical and thermal parameter enable the observation of TS value from the electrical circuit simulator's results. The simulation results are presented in the next section.

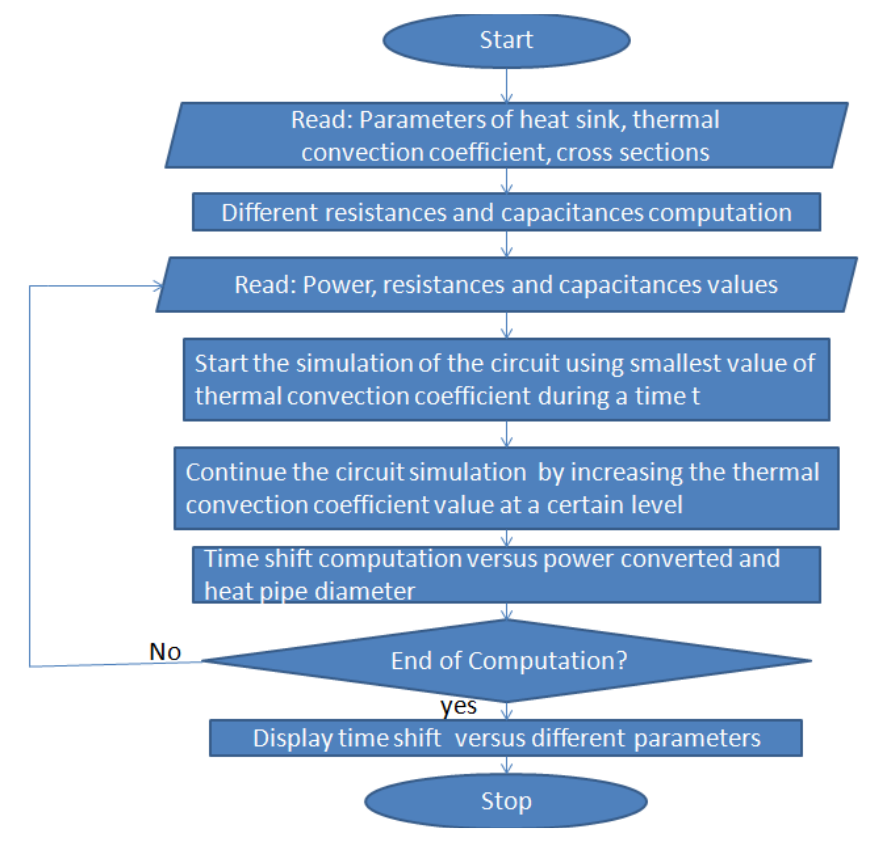

Fig.3 Algorithm of time shift computation

\section{Result and discussion}

Owing to the chip location (adiabatic environment), its cooling depends on heat pipe and heat sink thus the TS may occur when the thermal convection coefficient is raised at heat sink level. The thermal control of microsystem (microprocessor) contains turning on the fan close to the heat sink when the integrated circuit temperature reaches a certain level. This act automatically decreases the heat sink temperature while maintaining the constant temperature close to critical thermal threshold on the chip surface for a significant period of time. The time shift versus power (heat) absorbed/ released by the fluid inside heat pipe 
and pipe diameter may be visualized in Fig.4. The TS increases with power absorption by the fluid and pipe diameter. Both of them characterize the heat transfer capability of the heat pipe. Hence, an enhancement of cooling condition leads to rising TS. Finally, we conclude that the TS is proportional to cooling efficiency. The thermal compact model utilized is composed of elements required only for observation of time shift. The presented investigation focused on time shift phenomenon depending on the cooling efficiency could be a way to control chip operating frequency/voltage.

(a)

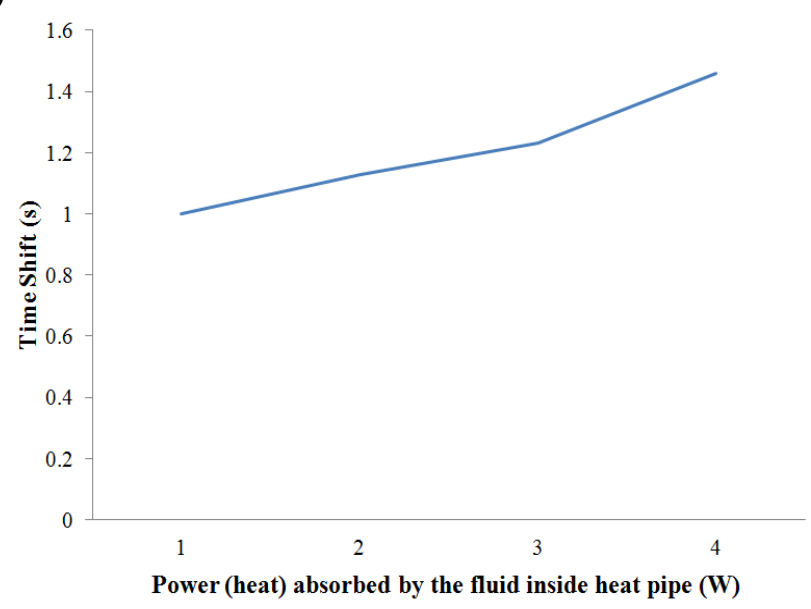

(b)

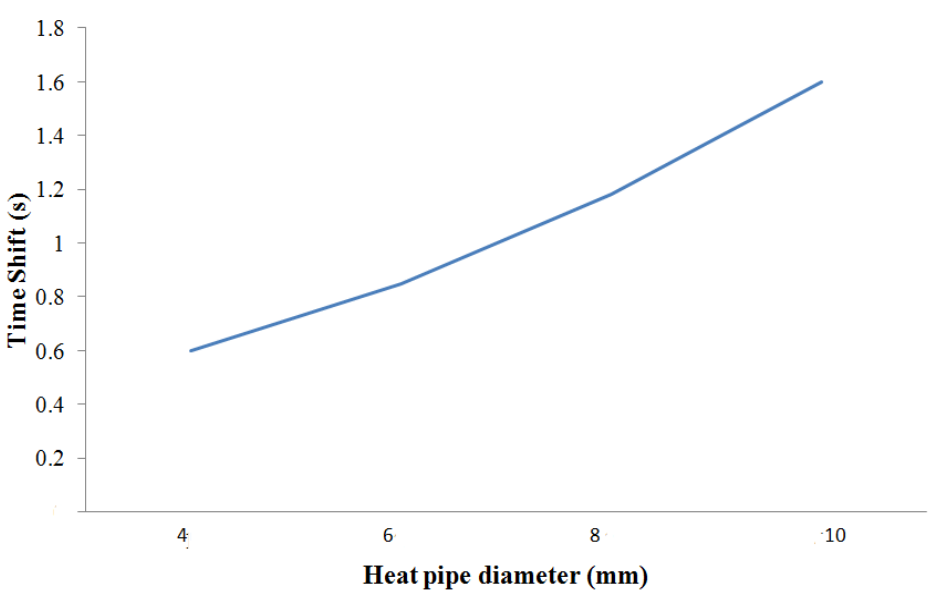

Fig.4 Time shift versus (a) power absorbed by heat pipe (b) diameter of heat pipe (Note that the heat pipe's length $1=150 \mathrm{~mm}$ and the thickness $\mathrm{d}=0.5 \mathrm{~mm}$ ) 


\section{Conclusion}

In this paper, the presented work shows the feasibility of frequency/voltage control using the information about cooling efficiency. Owing to this, in a significant period of time, the clock frequency generator may be accelerated while maintining the chip operating temperature constant and close to the critical thermal threshold without any delay. In most cases, the clock frequency and voltage are controled versus the information indicated by the temperature sensors located inside the chip. Remark that each reduction of operating frequency and voltage provokes an increase of the task execution time.

The thermal compact model based on analogy between thermal and electrical paramerters enables the observation of time shift scenario in electronic systems. The approach presented in this paper doesn't require any microcharcitectural changes of the system, the only exigency is the attachement of one additional temperature sensor at the edge of heat sink thus, its applicability might be simple and easy. The results might be useful for achieving the microsystem throughtput improvement by accelerating the clock generator frequency or increasing voltage supply over sufficient period of time. Finally, the maximum data processing of die can be achieved without any thermal violation.

Acknowledgment: The authors would like to express sincere gratitude to the National Science Centre for financial support, project grant FALCON 2014/13/B/ST7/01634.

\section{References}

[1] Coskum A. K., Ayala J. L., Atienza D., Rosing T. S. "Modeling and Dynamic Management of 3D Multicore Systems with Lquid Cooling" Very Large Scale Integration (VLSI-SoC), 2009 17th IFIP International Conference pp.35-40 12-140October 2009

[2] Frankiewicz M., Golda A., Kos A. "Investigation of Heat Transfer In Integrated Circuits" Metrology and Measurement Systems, vol.11, No.1, pp.111-120, 2014.

[3] Kim Y. G., Kim M., Kim J. M., Chung S.W. "M-DTM: Migration-based dynamic thermal management for heterogeneous mobile multi-core processors" Design, Automation \& Test in Europe Conference \& Exhibition (DATE), 2015, pp 1533-138, March 2015

[4] Kos A., De Mey G "Thermal Modelling and optimization of power microcircuits", Electrochemical Publications LTD, ISBN 0901150 3603, England 1997.

[5] Legierski J., Wiecek B., De Mey G. "Measurements and simulations of transient characteristics of heat pipes" microelectronics reliability, Vol. 46, issue1, pp.109115, January 2006. 
[6] O'Loughlin J., Loree D. “Cooling System Transient Analysis using an Electric Circuit Program Analog" Pulsed Power Conference, 2003. Digest of Technical Papers. PPC-2003. 14th IEEE International, Volume: 2, pp 767 - 770, June 2003.

[7] Pounds D., Bonner III R. W. "High Heat Flux Heat Pipes Embedded in Metal Core Printed Circuit Boards for LED Thermal Management" Thermal and Thermomechanical Phenomena in Electronic Systems (ITherm), 2014 IEEE Intersociety Conference on, pp 267-271, May 2014.

[8] Shaw M.C., Waldrop J. R., Chandrasekaran S., Kagalwala B., Jing X. "Enhanced Thermal Management by Direct Water Spray of High-Voltage, High Power Devices in a Three-phase, 18-hp AC Motor Drive Demonstration" Thermal and Thermomechanical Phenomena in Electronic Systems, 2002. ITHERM 2002. The Eighth Intersociety Conference on, pp. 1007-1014, 2002.

[9] Stavrou K., Trancoso P. "Thermal-Aware Scheduling: A solution for Future Chip Multiprocessors Thermal Problems" Digital System Design: Architectures, Methods and Tools, 2006. DSD 2006. 9th EUROMICRO Conference on, pp.123 - 126, 2006.

[10] Székely V., Rencz M., P'ahi A., Courtois B. "Thermal Monitoring and Testing of Electronic systems" IEEE Transactions on components and packaging technology, vol.22, No.2, pp.231-237, June 1999.

[11] Tockhorn A., Cornelius C., Saemrow H., Timmermann D. "Modeling Temperature Distribution in Networks-on-Chip using RC-Circuits" Design and Diagnostics of Electronic Circuits and Systems (DDECS), 2010 IEEE 13th International Symposium on, pp. 229 - 232, April 2010.

[12] Tworus K. “Application of Inverse Problems to On-line Temperature Monitoring of Integrated Circuits" 2002.

[13] Zhang P., Ruan L. "Experimental Study On Two-phase Spray Cooling For The Cooling of High-heat-flux Electronic Chip" 2012 Computer Distributed Control and Intelligent Environmental Monitoring (CDCIEM), 2012 International Conference on, pp.324-326, March 2012.

\section{ZWIĘKSZENIE WYDAJNOŚCI MIKROSYSTEMÓW Z UŻYCIEM NOWEGO SYSTEMU CHEODZENIA}

\footnotetext{
Streszczenie

Praca prezentuje nowy sposób sterowania napięciowo-częstotliwościowego procesorów o dużej wydajności numerycznej z wykorzystaniem informacji o bieżącej efektywności chłodzenia. Autorzy zaproponowali metodę sterownia, która lepiej wykorzystuje własności cieplne modułu scalonego w sensie bardziej efektywnego przekazywania ciepła do otoczenia. W tym celu wprowadzono i wyliczono czas przesunięcia (TS) aktywności numerycznej, zdefiniowany jako przedział czasu, w którym system cyfrowy może pracować ze zwiększoną efektywnością bez obawy o przekroczenie dopuszczalnej temperatury pracy. W szczególności, nawet wówczas gdy struktura scalona pracuje na granicy wytrzymałości termicznej. Do analizy termicznej wykorzystano model kompaktowy RC oparty na analogii elektrycznej. Do analizy wykorzystano program Spice. Otrzymane wyniki wskazują, że TS stanowi znaczącą cześć całkowitego czasu pracy procesora co przekłada się na zwiększenie częstotliwości lub napięcia zasilania, a zatem prowadzi do zwiększenia wydajności procesora.
} 
Słowa kluczowe: częstotliwość zegara taktującego, napięcie zasilania, rurki cieplne, czujniki temperatury, wydajność procesora

DOI: $10.7862 /$ re.2016.1

Tekst złożono w redakcji: styczeń 2016

Przyjęto do druku: marzec 2016 

